NBER WORKING PAPER SERIES

\title{
THE EFFECT OF FIRM-LEVEL CONTRACTS \\ ON THE STRUCTURE OF WAGES: \\ EVIDENCE FROM MATCHED EMPLOYER-EMPLOYEE DATA
}

\author{
David Card \\ Sara de la Rica \\ Working Paper 11829 \\ http://www.nber.org/papers/w11829 \\ NATIONAL BUREAU OF ECONOMIC RESEARCH \\ 1050 Massachusetts Avenue \\ Cambridge, MA 02138 \\ December 2005
}

\begin{abstract}
We thank two anonymous referees, Nicole Fortin, Thomas Lemieux, and seminar participants at the Lisbon meeting of the European Association of Labour Economists and the Berkeley Labor Lunch for comments and suggestions. Sara de la Rica gratefully acknowledges financial support from the FFBVA (1/BBVA 00044.321-15467/2002) and the Spanish Ministry of Education (BEC2003-04826). The views expressed herein are those of the author(s) and do not necessarily reflect the views of the National Bureau of Economic Research.
\end{abstract}

(C2005 by David Card and Sara de la Rica. All rights reserved. Short sections of text, not to exceed two paragraphs, may be quoted without explicit permission provided that full credit, including $\odot$ notice, is given to the source. 
The Effect of Firm-Level Contracts on the Structure of Wages: Evidence from Matched Employer-Employee Data

David Card and Sara de la Rica

NBER Working Paper No. 11828

December 2005

JEL No. J31, J50

\begin{abstract}
$\underline{\text { ABSTRACT }}$
In many European countries sectoral bargaining agreements are automatically extended to cover all firms in an industry. Employers and employees can also negotiate firm-specific contracts. We use a large matched employer-employee data set from Spain to study the effects of firm-level contracting on the structure of wages. We estimate a series of wage determination models, including specifications that control for individual characteristics, co-worker characteristics, the bargaining status of the workplace, and the probability the workplace is covered by a firm-level contract. We find that firm-level contracting is associated with a 5-10 percent wage premium, with larger premiums for more highly paid workers. Although we cannot decisively test between alternative explanations for the firm-level contracting premium, workers with firm-specific contracts have significantly longer job tenure, suggesting that the premium is at least partially a non-competitive phenomenon.

David Card Department of Economics

549 Evans Hall, \#3880

UC Berkeley

Berkeley, CA 94720-3880

and NBER

card@econ.berkeley.edu

Sara de la Rica

Depto. Fundamentos del Analisis Economico II

Universidad del Pais Vasco

Avenida Lehendakari Aguirre, 83

48015 Bilbao Spain

sara.delarica@ehu.es
\end{abstract}


In many European countries, industry-wide contracts negotiated by employer associations and unions are automatically extended to all workplaces. ${ }^{1}$ Individual employers can also sign firm-specific agreements with their employees. Despite the extensive literature linking differences in the centralization of wage contracting to cross-country differences in macroeconomic performance (e.g., Bruno and Sachs, 1985; Calmfors and Driffill, 1988; Nickell and Layard, 1999; Blanchard and Wolfers, 2000; Calmfors, 2001) there is much less evidence on how the level of contracting affects the structure of wages. ${ }^{2}$ Studies from the U.S. and U.K. suggest that decentralized collective bargaining tends to increase the mean and reduce the inequality of wages relative to non-union wage-setting (see Card, Lemieux, and Riddell, 2004 for a recent review). In countries with automatic extension of sectoral contracts, however, the key question is how decentralized bargaining compares to more centralized wage setting.

In this paper we use a detailed employer-employee data set from Spain to study how the level of contracting affects the structure of wages. Spanish law extends industry-level agreements negotiated at the regional or national level to all establishments, regardless of union membership. Fifteen percent of workers are covered by firm-specific contracts that override the prevailing sectoral agreement. Our data set includes information for up to 60 workers per firm at a random sample of larger workplaces. ${ }^{3}$ Comparisons across workers covered by different types of agreements suggest that the wage structure is very similar under national and regional

\footnotetext{
${ }^{1}$ Examples include Spain, Italy, the Netherlands, and Portugal.

${ }^{2}$ Previous studies of this issue include Dell'Aringa and Lucifora (1994), who examine a sample of manufacturing plants in Italy, Hartog, Leuven, and Teulings (2002), who study the Netherlands, Canal and Rodriguez (2004), who examine the effect of firm-level bargaining on wage inequality within firms in Spain, and Hartog, Pereira, and Vieira, 2005, who study the effects of the level of bargaining in Portugal. Bover, Bentolila and Arellano (2002) report some results on the impact of firm-level bargaining in Spain.

${ }^{3}$ The Workplace Industrial Relations Surveys conducted in Australia and the UK share a similar design, although these surveys have relatively small sample sizes compared to the Spanish survey.
} 
contracts, while wages negotiated under firm-specific agreements are systematically higher.

As noted in a recent study by Dinardo and Lee (2004), microeconometric studies of collective bargaining based on samples of workers may potentially confound bargaining status with other firm-level characteristics. ${ }^{4}$ In the absence of a research design for isolating exogenous variation in the probability of firm-level bargaining, we implement a propensity score-based method (Rosenbaum and Rubin, 1983; Imbens, 2004) to control for observed firm characteristics as flexibly as possible. Building on the structure of our data set, we estimate a model for the probability of firm-level contracting at a given establishment, and then include polynomial terms in the estimated probability (i.e., the propensity score) as controls in our individual-level models. We also estimate separate models for men and women in different skill groups. The results suggest that conventional wage determination models overstate the premium associated with firm-level contracting relative to our more flexible specifications. Combining the estimates by skill group and gender we find that firm-level contracting increases mean wages for both men and women, with a larger effect for more highly paid workers of either gender.

There are several competing explanations for the positive wage premium associated with firm-level contracts. The simplest is rent-sharing (e.g., Krueger and Summers, 1988;

Blanchflower, Oswald, and Sanfey, 1996). An alternative is that employees at workplaces with firm-level contracts are required to work harder, as in efficiency wage models (Akerlof, 1982; Akerlof and Yellen, 1988; Weiss, 1990; Mahuteau, 2002). A third possibility is that despite our best econometric efforts, the wage premium reflects unmeasured ability differences. These

${ }^{4}$ Using a U.S. sample of establishments that change union status as a result of a union certification election, DiNardo and Lee (2004) find no effect of union coverage on wages, contrary to the huge body of work based on individual level wages that finds a sizeable union premium. 
interpretations differ in the extent to which workers are better off under firm-specific contracting than under alternative arrangements, leading to different predictions about the relationship between firm-specific contracting and voluntary turnover. We therefore examine differences in job tenure associated with firm-specific contracts (Krueger and Summers, 1988). We find that average job tenures of men and women are about 2 years longer at workplaces with firm-specific contracts. Consistent with our finding that firm level contracting raises wages more for more highly skilled workers, the tenure gap is larger for more highly paid men, though not significantly so for women. These results lend some support for a simple rent-based explanation for the firm-specific contracting premium.

\section{Institutional Setting}

During the Franco era wage setting in Spain was centralized and highly regulated. Legally-recognized trade unions and employer groups negotiated contracts covering most jobs in the economy, subject to final approval by the state (Milner and Metcalf, 1994). The post-Franco constitution established a system for the election of worker representatives to regional or industry level bargaining units, organized along the lines of the earlier regime. ${ }^{5}$ The terms of the agreements reached at the industry and regional level between workers and employer groups are legally binding on all employers within the scope of the agreement. Thus, despite a relatively low rate of union membership (15 percent or less), collective bargaining coverage in Spain is

${ }^{5}$ The elections are in principle regulated by the state but de facto run by national unions. Most of the elected representatives are affiliated with one of the two major trade union organizations (the socialist UGT and the former communist CC.OO). The coverage of different agreements was largely inherited from the earlier regime (European Foundation for the Improvement of Living and Working Conditions, 1998). Bentolila and Jimeno (2002) discuss some key institutional features of the regulation of collective bargaining in Spain. 
very high ( 80 percent or more) ${ }^{6}$

At the firm level, worker representatives form works councils that negotiate over issues like staffing and absenteeism policies. They can also bargain over wages, and employees have the right to strike in support of demands for a firm-specific contract with wages above the scale of the prevailing sectoral contract. ${ }^{7}$ Data collected from contract agreements by Izquierdo, Moral, and Urtasun (2003) show that about 15 percent of Spanish workers were covered by firmlevel contracts in the early 1990s. Practitioners believe that firm-specific agreements are more likely to occur at firms with higher potential rents, and in workplaces where there is (or was) a strong union presence (Canal and Rodriguez, 2004). Consistent with these notions, firm-level contracting is more prevalent at larger firms, and in certain sectors, including extractive industries, energy, and transportation. We are unaware of any estimates of the rates that firmspecific contracts are established or dissolved. The relative coverage of different types of contracts in different industries was very stable over the 1990s (Izquierdo, Moral, and Urtasun, 2003, Tables A1 and A2), suggesting that contract status at a workplace is highly persistent.

The Spanish industrial relations system, comprised of a network of sectoral contracts overlaid with optional firm-specific agreements, is similar to the system in Italy (Dell'Aringa and Lucifora, 1994) and the Netherlands (Hartog, Leuven, and Teulings, 2002). The institution of firm-specific bargaining also shares some similarities with the system of decentralized collective bargaining in the "Anglo Saxon" countries. An employer's decision to accept a firm-

\footnotetext{
${ }^{6}$ Agriculture, food services, and household services industries have relatively low coverage. ${ }^{7}$ Legal reforms adopted in 1994 allow a firm contract to specify wages below the prevailing sectoral level. Before these reforms, firm-level contracts could only improve on conditions in the sectoral agreement (European Foundation for the Improvement of Living and Working Conditions, 1998).
} 
specific contract, for example, is comparable to the voluntary union recognition process in the U.K. (Disney, Gosling, and Machin, 1996). The bargaining process under firm-specific contracting presumably reflects the same combination of political and economic forces that influence unionized wage setting in the U.S. and the U.K. The key difference is the nature of the "default" wage structure. The alternative to a firm-specific contract in Spain is the prevailing sectoral contract, whereas in the U.S. and the U.K. the alternative is the nonunion labor market. This means that any comparison between the effects of firm-level bargaining in the Anglo Saxon countries and in countries with comprehensive sectoral agreements like Spain or Italy must be interpreted carefully. Even if workers' representatives share similar objectives across countries, firm-level bargaining may result in a more equal wage structure relative to the alternative in the U.S. or U.K., but a less equal wage structure relative to the alternative in Spain.

\section{Data Description and Preliminary Analysis}

To set the stage for our empirical analysis it is useful to briefly summarize the key features of our matched data set. The 1995 Spanish Wage Structure Survey (ESS95) surveyed around 15,000 establishments in the manufacturing, construction, trade, and service industries, collecting detailed salary and job information for up to 60 employees in each selected workplace. ${ }^{8}$ The unique design of the survey allows us to model wage outcomes at the employee level while including controls for co-worker and establishment characteristics. The main

\footnotetext{
${ }^{8}$ Establishments with at least 10 workers in the General Registry of Payments to Social Security were stratified by autonomous community and size. An average of 5 workers were selected at firms with 10-20 workers, an average of 7 at firms with 21-50 workers, an average of 12 at firms with 51-100 workers, an average of 23 at firms with 100-200 workers, and an average of 25 at employers with more than 200 workers. Establishments with 10 or more workers accounted for just over 70 percent of the total working population in Spain in 1995.
} 
limitation of the ESS95 is coverage: agriculture, mining, and household services are missing from the sample, as are small establishments (under 10 workers) and workers in the relatively large "underground" sector of Spanish economy who do not pay Social Insurance taxes (see Lemieux and de la Rica, 1994). ${ }^{9}$

For convenience we focus on the subsample of workers in the ESS95 with non-missing data on individual, job, and firm characteristics. We also exclude the relatively small fraction (under 5 percent) of part-time workers, yielding an analysis sample of about 130,000 workers at 14,300 establishments. Table 1 presents descriptive statistics for the overall sample and for workers covered by the three different levels of contracts: national contracts ( 35 percent of workers), regional contracts ( 42 percent of workers), and firm-specific contracts ( 23 percent of workers). ${ }^{10}$

Comparisons across the columns of Table 1 show that there are systematic differences between workers covered by different types of contracts. For example, employees at workplaces with firm-specific contracts are older, have a higher probability of holding a university education, and are a little less likely to be female. Two other key differences are temporary contract status and job tenure. Temporary contracts were introduced in Spain in 1984 as a way to encourage new hiring, and by the early 1990s accounted for nearly one-third of total employment. ${ }^{11}$ Although the law requires equal pay for temporary workers they earn lower

${ }^{9}$ Sisson et al. (1991) report that Spain has the highest fraction of workers at small establishments among EU countries.

${ }^{10}$ The prevalence of firm-specific contracts is higher in the ESS95 than in the workforce as a whole, reflecting the exclusion of small establishments and sectors like agriculture and household services.

${ }^{11}$ See Guell and Petrongolo (2003) and de la Rica (2004). Employees hired under temporary (or "fixed term") contracts can be readily terminated once their contract is over, whereas those hired under regular (or "indefinite") contracts can only be terminated under certain circumstances. 
wages, presumably because of differences in unobserved skills (de la Rica, 2004). As shown in

Table 1, establishments with firm-level contracts employ a lower fraction of temporary workers.

Since temporary contracts are limited to three years, there is a strong correlation between the fraction of temporary contracts at a workplace and the distribution of job tenure, partially explaining the higher average job tenure for workers covered by firm contracts.

The middle rows of Table 1 show that establishment characteristics also vary by contract type. Larger establishments, manufacturing plants, and plants that supply a regional or international market are more likely to offer firm-specific contracts. ${ }^{12}$ The establishment size differential is particularly important: nearly one-half of the workers covered by firm-level contracts are employed at establishments with 200 or more workers, compared with only 10 percent of workers covered by regional contracts and 22 percent of those covered by national agreements. Finally, the bottom rows of Table 1 show that occupational distributions are also different in the three contracting groups, with more managers and fewer service workers under firm-level contracts.

The employee compensation data in the ESS95 includes "base wages" and "wage complements". Base wages are determined from the appropriate contract by occupation and grade within a firm, while wage complements include factors like seniority and shift premiums,

Fixed-term contracts can be extended for up to three years, but after that point the employee must be terminated or offered a regular contract. Though firms are formally prohibited from filling jobs by cycling temporary workers, evidence in the size of the temporary workforce suggests that most young workers spend more than three years on temporary contract position before obtaining an indefinite contract.

${ }^{12}$ The best available information on the coverage of different contract types is from Izquierdo, Moral, and Urtasan's (2003) analysis of the universe of labor contracts. In the mid-1990s, they estimate that the average firm with a firm-level contract had about 300 workers, versus 200 for firms with national contracts, and 15 for firms with regional contracts. 
as well as discretionary supplements awarded to individual employees. The ESS95 survey gathered information from company records on both components, and we use the sum of these two, expressed in pesetas per hour, as our measure of compensation. Table 2 presents means and standard deviations of log hourly wages for men and women in the overall sample and in the three different contract sectors. The first two columns show the unadjusted sample moments, while columns 3 and 4 show adjusted moments, obtained using the re-weighting technique of DiNardo, Fortin, and Lemieux (1996) to adjust the distribution of observed characteristics for each contract sector back to the overall distribution. ${ }^{13}$ We calculated the weights for this procedure using separate probit models for the probability of employment in each of the three sectors. The explanatory variables for these probit models include age, education, industry (6 dummies), occupation (4 dummies), market orientation ( 2 dummies), and firm size (5 dummies).

Without adjusting for differences in observed worker and firm characteristics, wages are lower under regional contracts than national contracts, and higher under firm-level contracting. Standardizing for the observed characteristics, however, mean wages in regional and national contracts are nearly identical, while wages under firm-level contracts are 10-12 percent higher for both men and women. Wage dispersion is a little higher in national contracts than firmspecific contracts, and substantially lower in regional contracts. Again, however, standardizing for the observed skill characteristics brings the regional and national sectors into very close alignment. Based on the evidence in Table 2 and related analysis we conclude that the structure

\footnotetext{
${ }^{13}$ In brief, the DiNardo Fortin Lemieux procedure estimates the relative probability that a worker with given characteristics is employed in the overall sample and in a given sub-sector, and uses this probability to "up-weight" or "down-weight" workers who are under- or over-represented in the sub-sector so that the weighted distribution of skill characteristics is the same in the subsector as the overall sample.
} 
of pay is very similar under regional and national contracts in Spain, and for the remainder of this paper we group the two together and focus on the contrast between firm-specific and sectorlevel contracts. ${ }^{14}$

Although the results in Table 2 give some indication of how mean wages vary by contracting sector, they do not address the issue of whether the type of contract exerts a different effect on different types of workers. Bover, Bentolila and Arellano (2002), for example, have argued that collectively-bargained wage levels are only relevant for less-skilled workers in Spain, suggesting that choice of contract type may have little effect on highly-skilled workers. To provide some simple evidence on this issue, we estimated the mean log wages of men and women in narrowly-defined age-education cells working under firm-specific and sectoral (national or regional) contracts. Specifically, we divided workers into 56 cells, using 8 age categories and 7 education ranges. We then graphed the mean wages of workers with firmspecific contracts against the means for the same age-education group under centralized bargaining.

The results are shown in Figures 1 and 2. For reference, each graph also shows the 45 degree line. If mean wages were the same in the two sectors the points would lie along this line. Examination of the graph shows that the points actually lie above the 45 degree line, with a scatter that is roughly parallel to the 45 degree line for men and a little steeper for women. These simple graphs suggest that firm-level contracting raises wages relative to sectoral contracting in Spain, with a premium that is slightly higher for older and better-educated women,

\footnotetext{
${ }^{14}$ Canal and Rodriguez (2004) likewise combine workers covered by regional and national contracts.
} 
but roughly similar across groups for men. ${ }^{15}$

An important limitation of these comparisons is that we are not controlling for other factors - e.g., firm size - that may be correlated with the incidence of firm-specific contracting and may also exert a direct effect on wages. To extend the analysis we need a more complete econometric model of the wage determination process.

\section{Empirical Framework}

Our formal analysis of wage outcomes in the ESS95 data is based on a model of earnings for worker $\mathrm{i}$ at establishment $\mathrm{j}$ of the form:

$$
y_{i j}=X_{i} \beta+\delta_{i j}+a_{i}+\epsilon_{i j},
$$

where $\mathrm{y}_{\mathrm{ij}}$ represents the $\log$ hourly wage of individual $\mathrm{i}, \mathrm{X}_{\mathrm{i}}$ is a set of observed skill characteristics (such as age and education) of worker $i, a_{i}$ represents any unobserved skill characteristics, $\delta_{\mathrm{ij}}$ represents the wage premium earned by worker $\mathrm{i}$ at workplace $\mathrm{j}$ (including the possible impact of having a firm-level contract at the workplace), and $\epsilon_{\mathrm{ij}}$ is a stochastic error component. To model the effect of firm-level contracting, we assume that the wage premium for worker $\mathrm{i}$ at workplace $\mathrm{j}$ depends on four factors: the average characteristics of all workers at the workplace $\left(\mathrm{X}_{\mathrm{j}}\right)$, a vector of firm-level covariates $\left(\mathrm{Z}_{\mathrm{j}}\right)$, an indicator for the presence of a firmspecific contract $\left(\mathrm{F}_{\mathrm{j}}\right)$, and an unobserved firm-level component $\left(\mathrm{v}_{\mathrm{j}}\right)$ :

$$
\delta_{i j}=X_{j} \eta+F_{j} \alpha+Z_{j} \gamma+v_{j}
$$

These assumptions lead to a model for individual wages of the form:

\footnotetext{
${ }^{15}$ Similar graphical comparisons of union and nonunion wages in the U.S., Britain, and Canada show that in Anglo Saxon countries firm-level collective bargaining tends to raise wages more for less skilled workers, relative to the non-union sector (Card, Lemieux, and Riddell, 2004).
} 


$$
\mathrm{y}_{\mathrm{ij}}=\mathrm{X}_{\mathrm{i}} \beta+\mathrm{X}_{\mathrm{j}} \eta+\mathrm{F}_{\mathrm{j}} \alpha+\mathrm{Z}_{\mathrm{j}} \gamma+\mathrm{a}_{\mathrm{i}}+\mathrm{v}_{\mathrm{j}}+\epsilon_{\mathrm{ij}},
$$

which includes individual-level controls, co-worker characteristics, firm characteristics, contract status, and an establishment-level error component. Assuming that $\mathrm{a}_{\mathrm{i}}$ and $\mathrm{v}_{\mathrm{j}}$ are uncorrelated with contract status (conditional on the observed worker and firm characteristics), the firm-level contract effect $\alpha$ can be estimated consistently by a conventional (OLS) regression applied to (3). An identical estimate of $\alpha$ can be obtained by estimating a model for the average wage at each establishment that includes average worker characteristics, the vector of firm-level covariates $Z_{j}$ and the contract status indicator $F_{j} \cdot{ }^{16}$

More generally, unobserved worker or firm characteristics may be correlated with contract status, leading to potential biases in the estimation of $\alpha$. In particular, suppose that $\mathrm{a}_{\mathrm{i}}$ varies across workers, with

$$
E\left[a_{i} \mid X_{i}, X_{j}, Z_{j}, F_{j}\right]=X_{i} \phi_{a}+X_{j} \lambda_{a}+Z_{j} \theta_{a}+F_{j} \mu_{a}
$$

and similarly, suppose that $\mathrm{v}_{\mathrm{j}}$ varies across firms with

$$
E\left[v_{j} \mid X_{i}, X_{j}, Z_{j}, F_{j}\right]=X_{j} \lambda_{v}+Z_{j} \theta_{v}+F_{j} \mu_{v}
$$

Combining these equations with equations (1) and (2), the correctly specified worker level model is

$$
\begin{aligned}
y_{i j}=X_{i}\left(\beta+\phi_{a}+\phi_{v}\right)+X_{j}\left(\eta+\lambda_{a}+\lambda_{v}\right)+Z_{j}\left(\gamma+\theta_{a}+\theta_{v}\right)+F_{j}\left(\alpha+\mu_{a}+\mu_{v}\right) \\
+a_{i}^{\prime}+v_{j}^{\prime}+\epsilon_{i j}
\end{aligned}
$$

where $\mathrm{a}_{\mathrm{i}}^{\prime}$ and $\mathrm{v}_{\mathrm{j}}$. represent unobserved ability and workplace components that are orthogonal to the observed data. Consideration of this model shows that if contract status is correlated with either the unobserved ability of workers or unobserved firm-specific wage factors, then the

\footnotetext{
${ }^{16}$ The estimate of $\alpha$ will only be the same if the firm level model is estimated by weighted least squares, using the number of workers observed at the firm as a weight.
} 
measured effect of a firm-level contract will include the true effect $(\alpha)$ as well as the bias factors $\mu_{\mathrm{a}}$ and $\mu_{\mathrm{v}}$.

The possibility of a systematic correlation between unobserved ability and contract status is often raised in discussions of the measured union wage effect in Anglo-Saxon countries. Lewis (1986), for example, argued that unionized employers in the U.S. can choose from a queue of applicants, leading to positive correlation between union status and unobserved ability. ${ }^{17}$ One advantage of our data set is the availability of information on the characteristics of co-workers. Under plausible assumptions on the hiring process, workers with higher unobserved ability will tend to have co-workers with higher average skills (and conversely for workers with low unobserved ability), implying that some of the effects of unobserved ability will be eliminated by controlling for co-worker skills. Thus, we believe that unobserved ability effects are likely to be less of a problem for specifications that control for co-worker characteristics than in the usual case where co-worker characteristics are unknown.

Though the issue has received less attention in the literature on union wage determination, a similar problem arises in the presence of unobserved firm-specific wage factors. ${ }^{18}$ Dinardo and Lee (2004), for example, argue that union status in the U.S. is correlated with firm-level characteristics associated with higher wages. In the absence of a research design for isolating exogenous differences in contracting status, we follow an alternative approach of

${ }^{17}$ Evidence from union status changers (Lemieux, 1993; Card, 1996) suggests this is true for workers with low observed skills, but that the opposite pattern arises for workers with higher observed skills, so that on average the bias is modest.

${ }^{18}$ The lack of attention to firm-specific factors could be attributed to the fact that in a standard neoclassical model, there are no firm-specific components of wages. It is widely acknowledged, however, that wages vary with many characteristics of firms, including firm size (see Idson and Oi, 1999). 
attempting to control as flexibly as possible for the full set of observed firm-level characteristics that determine the level of bargaining. As shown in Imbens (2004), if contract status is "ignorable" (i.e., as good as random) conditional on the observed control variables (including the mean characteristics of the workforce, industry, and firm size) then conditioning on the probability $\mathrm{p}\left(\mathrm{Z}_{\mathrm{j}}, \mathrm{X}_{\mathrm{j}}\right)$ that establishment $\mathrm{j}$ has a firm-level contract will eliminate any bias in the estimation of $\alpha$ arising from the correlation with firm characteristics. We implement this idea by first fitting a probit model for the probability of a firm level contract, and then including a polynomial function of the predicted probability from this model as an additional set of control variables in our wage equation.

The advantage of this approach is that it provides a simple and parsimonious way to control for effects of the observed variables that affect the probability of having a firm-level contract: all the relevant information is condensed into the one-dimensional propensity score. Like a regression approach, propensity-score based methods can only provide valid estimates if there are no differences in unobserved wage determinants that vary by contract status. However, models that control for the estimated propensity score are in principle more robust to functional form issues (Imbens, 2004).

\section{Wage Determination Models}

We turn now to the estimation of models for individual-level wage outcomes in the ESS95. Table 3 presents a series of regression models for male and female workers that include an indicator for firm-level contracting status and a variety of other control variables. The models are estimated by weighted least squares, using the sampling weight for each worker as a 
weight. ${ }^{19}$ The first model for each gender group (specification [1]) includes only a dummy for firm-level contracting. This has an estimated coefficient of just over 30 percent for both men and women, suggesting a very large wage premium for firm-level contracting. As shown by the results from specification [2], however, two-thirds or more of this gap is explained by differences in the characteristics of workers and firms with firm-level contracts. The covariates in this specification include the individual worker's age and education, a dummy indicating whether he or she is employed on a temporary contract, a vector of controls for the market orientation and public ownership status of the firm, and dummies for establishment size, occupation, industry, and region. Many of the control variables are highly significant, and their inclusion raises the R-squared statistics to around $50 \%$. These models are similar to the specifications fit in many previous studies of wage determination in the U.S., the U.K., and continental Europe, and yield estimated premiums for firm-level bargaining that are comparable to (or a little smaller than) the unionized wage premiums typically estimated in the U.S.

As we noted in Section III, a potential issue in the estimation of the wage premium associated with firm-level contracting is the presence of unobserved ability differences across workers. One way to partially control for the associated biases is to include measures of the skill characteristics of co-workers in similar positions at the same firm. Controlling for a worker's observed skills, a higher level of co-worker skills implies that the worker has above-average unobserved skill characteristics. Conversely, lower co-worker skills suggest below-average unobserved skills. The models in the third and sixth columns of Table 3 add mean co-worker

\footnotetext{
${ }^{19}$ The ESS95 sampling weights reflect the relative probabilities of sample selection for different establishments, and are the same for all workers from a given establishment. Since our sample includes multiple observations per employer, the standard errors are calculated allowing a shared error component (i.e., "clustered" by employer).
} 
characteristics, averaged over all employees at the same establishment in the same broad occupational group. ${ }^{20}$ Comparisons of the models with and without the co-worker variables suggest that the addition of these controls leads to a $10-15 \%$ reduction in the estimated effect of firm-level contracting. The addition of co-worker characteristics also reduces the measured impacts of the corresponding individual variables. For example, comparing models [2] and [3], the addition of co-worker characteristics reduces the coefficient of individual education by about $8 \%$ for men and $19 \%$ for women and the coefficient of individual age by about $10 \%$ for men and $20 \%$ for women. The fraction of female co-workers also has a strong negative impact on individual wages. ${ }^{21}$ According to the results from specification [3] in Table 3, a switch from having all-male co-workers to all-female co-workers is associated with a 5\% reduction in wages for men and $16 \%$ reduction for women.

\section{Adding Controls for the Probability of a Firm-Specific Contract}

A second source of potential bias in the estimated wage premium for working under a firm-specific contract is the presence of workplace-specific factors that are correlated with the presence of a firm-specific contract. As discussed earlier, our approach to this problem is to augment the wage models for men and women with a low order polynomial function of the estimated probability of having a firm-level contract at the individual's workplace.

\footnotetext{
${ }^{20} \mathrm{We}$ have also fit models in which include the mean wage of all co-workers, and coworkers in narrower occupational subgroups. Appendix Table A1 reports several alternative specifications. The results from these models are quite similar to results reported in Table 3.

${ }^{21}$ There is an extensive North American literature relating wages to the fraction of women in the occupation or job classification - see e.g. Johnson and Solon (1986) and Baker and Fortin (2001). De la Rica (2003) conducts an extensive analysis of the gender wage gap in the ESS95, focusing on the effects of gender composition.
} 
We began by fitting a flexible probit model (at the workplace level) for the incidence of a firm-specific contract, using as covariates the mean age and education of the workforce, the fractions of workers in different occupation groups, the fraction of female workers and workers with a temporary contract, dummies for the market orientation of the firm and the size of the establishment, and controls for industry and region. We then formed the predicted probability (or propensity score) for each workplace, and assigned this to the corresponding group of workers. Finally, we estimated a variant of the specification [3] from Table 3 that includes a third-order polynomial in the estimated propensity score.

The results are summarized in Table 4. For convenience, we show only the estimated firm-specific contracting effects, and the coefficients of the propensity score terms. (The other coefficients are quite similar to the coefficients from the corresponding models in Table 3 ). The estimates suggest that it is important to control flexibly for the different characteristics of employers that do and do not offer firm-specific contracts, particularly for men. Relative to the models that exclude the propensity score terms, the estimated premiums in Table 4 are are about $30 \%$ smaller. The implied values of the propensity score terms are also interesting, since these indicate the wage differences associated with different propensities, irrespective of the actual contract status. For men, the polynomial is concave, rising from 0 at $\mathrm{p}=0$ to 0.12 at $\mathrm{p}=0.4$, and 0.16 at $\mathrm{p}=0.8$. For women, the polynomial is nearly linear, reaching 0.09 at $\mathrm{p}=0.4$ and 0.23 at $\mathrm{p}=0.8$. Since firms that actually offer firm-level contracts tend to have higher propensities, adding the polynomial in the propensity score lowers the estimated wage premium for firm-level contracting. We suspect that the propensity score terms control for some important interactions between industry, firm size, and worker characteristics that are missing from the more conventional specifications in Table 3. 
Analysis by Skill Group

Although the models in Tables 3 and 4 show the effect of firm-level contracting on mean wages, they do not address the question of whether the effect is different for different skill groups. To answer this question, we fit a series of separate models for workers in different wage quintiles. We began by calculating the 20 th, 40 th, 60 th and 80 th percentiles of the wage distributions of men and women. We then estimated ordered probit models, separately by gender, to predict the probability that a given person would earn a wage in one of the five quintile ranges. The prediction models include age and education, temporary contract status, and occupation dummies (see Appendix A2). We then used the predicted probabilities as weights and estimated 5 separate models for each gender, in each case weighting an individual observation by his or her predicted probability of earning a wage in the given quintile. The advantage of this method, over alternative deterministic classification methods, is that it takes account of the uncertainty in predicting wage outcomes.

Table 5 summarizes the estimated firm-level contract effects from four different versions of these quintile-specific wage models. The different models correspond to the specifications in Tables 3 and 4: model [1] includes only a firm-contract dummy; model [2] adds individual and firm characteristics; model [3] adds co-worker characteristics; and finally model [4] adds a cubic in the predicted probability of a firm level contract at the individual's workplace. For reference, we also show the fraction of workers with firm-specific contracts in each wage group.

For men, the estimated effects of working under a firm level contract are roughly constant across wage groups when we exclude any other controls, but in models [2]-[4] there is a tendency for a higher premium among higher-wage groups. Our most general specification 
suggests that the premium rises from $5 \%$ to nearly $9 \%$ between the lowest and highest wage groups. Thus, it appears that firm-specific contracting raises the magnitude of skill differentials relative to sectoral contracting. Nevertheless, the effect is relatively modest: the mean wage gap between quintiles 1 and 5 is predicted to be about 4 percentage points wider for workers paid under firm-specific contracts. An interesting feature of the quintile specific wage effects in Table 5 is that the average of the estimated effects across the five quintiles tends to be bigger than the estimated effect from corresponding model fit to the pooled sample of men in Table 3 or 4. We suspect the discrepancy arises from the fact that the overall model restricts the effects of the covariates to be the same at different points in the wage distribution, whereas the quintilespecific models relax this restriction.

The results for women are similar to the results for men, although among women there is an even stronger tendency for the contracting premium to rise across the wage quintiles. In our most general specification (model [4]), the premium for the lowest-wage women is nearly zero, while the premium for women in the top quintile is $10.1 \%$. Thus, the wage gap between quintiles 1 and 5 is predicted to be about 9 percentage points wider for women paid under firmspecific contracts than under sectoral contracts.

Taken as a whole, the results in Tables 3-5 point to three main conclusions. First, there is a positive wage premium associated with firm-level contracting in Spain. Given the institutional setting, we believe this makes sense. Worker representatives only have an incentive to establish a firm-specific contract if they think that such an agreement will yield more favorable terms that the default sectoral contract. Moreover, although in our sample period firm-specific contracts could technically offer wages below the prevailing sectoral contract, until just a year before the ESS95 survey this was not allowed. A second conclusion is that the average wage premium is 
relatively modest: almost surely under 10 percent, and perhaps as low as 5 percent. In wage models with controls for worker, firm, and co-worker characteristics the premium is on the order of 7-11 percent. Adding additional controls for the probability of a firm-level contract at the individual's workplace lowers the estimated premium to a range of 5-8 percent. A third conclusion is that the premium for firm-specific contracting is higher for more highly-paid workers. This result contrasts with the unionized wage premium in the U.S. and U.K., which is generally found to be lower for more highly-paid workers, at least among men.

\section{Analysis of Job Tenure}

The evidence we have assembled so far suggests there is a positive wage premium associated with firm-level contracting that tends to rise with skill level. The simplest interpretation is that the premium represents a rent, captured by works councils with enough bargaining power to negotiate a contract offering wages above the prevailing sectoral agreement. The fact that firms voluntarily sign such contracts, however, raises the possibility of alternative interpretations, such as an efficiency wage premium. Even if the wage gains associated with a newly negotiated firm-level contract are initially pure rents, over time employers have strong incentives to "recapture" the rents by boosting effort levels or raising recruiting standards, converting the rent premiums into compensating wage differentials or unmeasured ability effects.

One way to evaluate the alternative interpretations is to examine differences in job tenure by contracting status. If the wage premium is a compensating wage differential, or a return to unmeasured ability, it should not necessarily affect job tenures. If the premium includes a rent component, however, then it should reduce voluntary turnover, leading to longer job durations at 
establishments with firm-specific contracts. Of course differences in observed tenure reflect many other factors, including differences in firm growth rates and retirement patterns, so the power of the evidence is limited.

Table 6 presents a series of regression models for observed job tenure, fit to the subsample of workers in the ESS95 between the ages of 24 and 65 . In an attempt to control as flexibly as possible for differences in the relative numbers of young and old workers in the different contract sectors, all the models include a full set of age dummies. Specifications [2] and [3] also include controls for education, region, occupation, industry, firm market orientation, and firm size. In addition, the third specification includes an interaction between the firmspecific contract dummy and the predicted log wage for each worker (estimated using data for workers with sectoral contracts only). The interaction term provides a simple way to measure how the gap in job tenure at workplaces with firm-specific contracts varies across the skill distribution. $^{22}$

The results from specification [1] imply that workers covered by firm-level contracts have 4-5 years of additional job tenure, relative to those of the same age in the other sector. Some of this is clearly attributable to firm size and the other control variables: the gaps drop to just over 2 years in specification [2]. This gap is a little smaller in magnitude than the 3.2 year difference in tenure for unionized U.S. workers measured by Krueger and Summers (1988, Table IX).

The results of the interacted specifications suggest that the impact of a firm-specific contract on job tenure is significant bigger for more highly skilled men. The point estimate

\footnotetext{
${ }^{22}$ The models used to predict the wage include the same variables used in the tenure model, so the "main effect" of the predicted wage is not identified.
} 
suggests that the sectoral difference in mean tenure rises by 1 year for each 40 percent increase in expected wages. Since our estimates of the firm-specific contracting effect on wages show a larger effect for higher-wage men, the positive interaction effect is consistent with a very simple rent explanation. For women, however, the interaction effect is only about one-sixth as big, and is not statistically significant. Since we also find a larger wage premium for higher-wage women, the lack of a large or significant interaction effect in the tenure model is less supportive of the rent hypothesis. Overall, there is clear evidence that workers stay longer at jobs covered by firm-specific contracts, but the variation in this effect across skill groups is only partially explained by the pattern of contracting effects on wages of different skill groups.

\section{Interpretation and Conclusions}

In this paper we use a matched worker-firm data set to examine the impact of firm-level contracting on the level and structure of wages in Spain. We find that wages set by firm-level contracting are higher than wages governed by industry-wide or national contracts. We also find that firm-level contracts tend to raise wages more for more highly-paid workers. The wage premium for firm-level bargaining is associated with longer job tenures, suggesting that at least some of the premium is a non-competitive rent, although the absence of a bigger tenure effect for more highly skilled women means that structure of the premium cannot be fully explained by relative rents.

Our findings contrast with the results of Hartog, Leuven, and Teulings (2002) who report that mean wages under firm-specific and industry-level contracting are very similar in the Netherlands. They explain the absence of a premium for firm-level contracting as a consequence of the corporatist Dutch system, in which unions do not operate as aggressive local rent seekers. 
Our findings are more consistent with the results of Dell'Aringa and Lucifora (1994), who find a statistically significant pay advantage (on the order of 5\%) for manufacturing workers in Italy whose wages are set by a firm-level contract. Interestingly, Dell'Aringa and Lucifora conclude that firm-level bargaining raises wages more for white collar workers than blue collar workers, paralleling our findings across wage quintiles in Spain.

The tendency for firm-level contracting to raise the relative wages of more highly-paid workers is the opposite of the decentralized bargaining effect in the U.S. or the U.K., where union contracts tend to "flatten" wages across skill groups relative to the non-union sector. In the Spanish system of extended sectoral contracts, however, the alternative to an establishmentlevel agreement is a regional or national agreement, which may itself impose a relatively flat wage structure. Thus, there is some indication that firm-level bargaining leads to a more "flexible" wage structure. The pattern of wage premiums for firm-level contracting also suggests that collective bargaining matters for all skill groups, not just lower-skilled workers, as has been hypothesized by Bover, Bentolila and Arellano (2002).

An caveat to these conclusions is that there may be unobserved skill differences between workers covered by firm-level and sectoral contracts. Our data set includes a relatively rich set of employer and employee characteristics, including the mean characteristics of co-workers which provide a useful proxy for unobserved ability components. We have also tried to control as flexibly as possible for observed differences in the characteristics of workplaces that have sectoral versus firm-specific contracts. Nevertheless, employers forced to pay a wage premium under a firm-specific contract have incentives to seek out the most qualified workers, and this mechanism may lead to systematic differences in unobserved characteristics that cannot be fully eliminated in an observational study. 
References

Akerlof, George (1982). "Labor Contracts as Partial Gift Exchange." Quarterly Journal of Economics 97(4), pp. 543-69.

Akerlof, George and Janet L. Yellen (1988). "Fairness and Unemployment." American Economic Review, 78 (2), pp. 44-49.

Baker, Michael and Nicole Fortin (2001). "Occupational Gender Composition and Wages in Canada: 1987-1988," Canadian Journal of Economics 34 (2), 345-376.

Bentolila, Samuel and Juan F. Jimeno (2002), “La Reforma de la Negociación Colectiva en España.” FDEA Working Paper 2002-03. Madrid: FEDEA.

Blanchard, Olivier and Justin Wolfers (2000). "The Role of Shocks and Institutions in the Rise of European Unemployment: The Aggregate Evidence." Economic Journal 110(2), pp. C1C33.

Blanchflower, David, Andrew Oswald and Peter Sanfey (1996). "Wages, Profits and Rent-Sharing." Quarterly Journal of Economics 111 (1), pp. 227-251.

Bover, O., S. Bentolila and M. Arellano (2002). “The Distribution of Earnings in Spain During the 1980s: The Effects of Skill, Unemployment and Union Power.” CEPR Discussion Paper Series, Labour Economics, Nº. 2770. London: CEPR.

Bruno Michael and Jeffrey Sachs (1985). Economics of Worldwide Stagflation. Cambridge, MA: Harvard University Press.

Canal Dominguez, Juan Francisco and Cesar Rodriquez Gutierrez (2004). "Collective Bargaining and Within-Firm Wage Dispersion in Spain.” British Journal of Industrial Relations $42(3), 481-506$.

Card, David (1996). "The Effect of Unions on the Structure of Wages: A Longitudinal 
Analysis." Econometrica 64 (4), 957-979.

Card, David (2001). "Immigrant Inflows, Native Outflows and the Local Labor Market Impacts of Higher Immigration.” Journal of Labor Economics 19 (1), pp. 22-65.

Card, David, Thomas Lemieux and W.Craig Riddell (2004). "Unionization and Wage Inequality." Journal of Labor Research 25 (4), pp. 519-562.

Calmfors, L. and J. Driffill (1988). "Bargaining Structure, Corporatism and Macroeconomic Performance.” Economic Policy 6, pp. 13-61.

Calmfors, L. (2001). "Wages and Wage-Bargaining Institutions in the EMU: A Survey of the Issues." CESifo Working Paper 520. Munich: CESifo.

De la Rica, Sara (2003). “Decomposing the Gender Wage Gap: The Effects of Firm, Occupation, and Job Stratification.” UC Berkeley Center for Labor Economics Working Paper No. 64. Berkeley: Center for Labor Economics.

De la Rica, Sara (2004). "Wage Gaps Between Workers with Indefinite and Fixed-term Contracts: The Impact of Firm and Occupational Segregation." Moneda y Crédito, 219, pp: 4369.

Dell’Aringa, Carlo and Claudio Lucifora (1994). "Collective Bargaining and Relative Earnings in Italy.” European Journal of Political Economy 10, pp. 727-747.

Disney, Richard, Amanda Gosling and Stephen Machin (1996). "What Has Happened to Union Recognition in Britain?” Economica 63 (249), pp. 1-18.

DiNardo, J. N. Fortin and T. Lemieux (1996). "Labor Market Institutions and the Distribution of Wages, 1973-88: A Semi-Parametric Approach.” Econometrica 64(5), pp. 10011044

Dinardo, John E. and David S. Lee (2004). “Do Unions Cause Business Failures?” 
Unpublished Working Paper, UC Berkeley Department of Economics. Available at http://emlab.berkeley.edu/users/dslee/index.shtml.

European Foundation for the Improvement of Living and Working Conditions (1998) "Spain's First Sectoral Agreement on the Structure of Collective Bargaining." Available at http://www.eiro.eurofound.ie/1998/05/feature/es9805153f.html.

Guell, Maia and Barbara Petrongolo (2003). "How Binding Are Legal Limits?

Transitions from Temporary to Permanent Work in Spain.” IZA Discussion Paper No. 782. IZA: Bonn.

Hartog, Joop, Edwin Leuven, and Coen Teulings (2002). "Wages and the Bargaining Regime in a Corporatist Setting: The Netherlands.” European Journal of Political Economy 18, pp. 317-331.

Hartog, Joop, Pedro T. Pereira and Jose A. C. Vieira (2005). "Bargaining Regimes and Wages in Portugal." University of the Azores Department of Economics Unpublished Working Paper.

Idson, Todd and Walter Y. Oi (1999). "Firm Size and Wages.” In Orley Ashenfelter and David Card, Editors, Handbook of Labor Economics (Volume 3B). Amsterdam: Elsevier. Imbens, Guido. (2004). “Nonparametric Estimation of Average Treatment Effects Under Exogeneity: A Review.” Review of Economics and Statistics 86(4), pp. 4-29. Izquierdo, Mario, Esther Moral, and Alberto Urtasun (2003). "Collective Bargaining in Spain: An Individual Data Analysis.” Bank of Spain Occasional Discussion Paper \#0302. Madrid: Bank of Spain.

Johnson, George and Solon, Gary (1986). "Estimates of the Direct Effects of Comparable Worth Policy." American Economic Review 76 (5), pp. 1117-1126. 
Krueger, Alan B. and Lawrence H. Summers (1988). "Efficiency Wages and the InterIndustry Wage Structure." Econometrica, 56 (2), pp. 259-293.

Lemieux, Thomas (1993). "Unions and Wage Inequality in Canada and the United States.” In David Card and Richard B Freeman, editors, Small Differences that Matter: Labor Markets and Income Maintenance in Canada and the United States. Chicago: University of Chicago Press for NBER.

Lemieux, Thomas and Sara de la Rica (1994). "Does Public Health Care Reduce Labor Market Flexibility or Encourage the Underground Economy? Evidence from Spain and the United States.” In Rebecca M. Blank, Editor, Social Protection vs. Economic Flexibility: Is there a Tradeoff? Chicago: University of Chicago Press for NBER.

Lewis, H. Gregg (1986). Union Relative Wage Effects: A Survey. Chicago: University of Chicago Press.

Mahuteau, Stephane (2002). "Reciprocal Fairness and Gift Exchange Practices in the Labor Market." Unpublished Working Paper, University of Western Sydney School of Economics \& Finance.

Milner, Simon and David Metcalf (1994). Spanish Pay Setting Institutions and Performance Outcomes. Banco de Espana Documento de Trabajo No. 9420. Madrid: Banco de Espana.

Nickell, Stephen and Richard Layard (1999). "Labor Market Institutions and Economic Performance." In Orley Ashenfelter and David Card, Editors, Handbook of Labor Economics Volume 3C. Amsterdam: Elsevier.

OECD (1994). Employment Outlook Paris: OECD.

Rosenbaum, Paul R. and Donald B. Rubin (1983). "The Central Role of the Propensity 
Score in Observational Studies for Causal Effects.” Biometrika 70(1), pp. 41-55.

Sisson, K., J. Waddington, and C. Whitson (1991). "Company Size in the European

Community." Human Resource Managament Journal 2 (1), pp. 94-109.

Weiss, Andrew (1990). Efficiency Wages: Models of Unemployment, Layoffs, and Wage

Dispersion. Princeton NJ: Princeton University Press. 


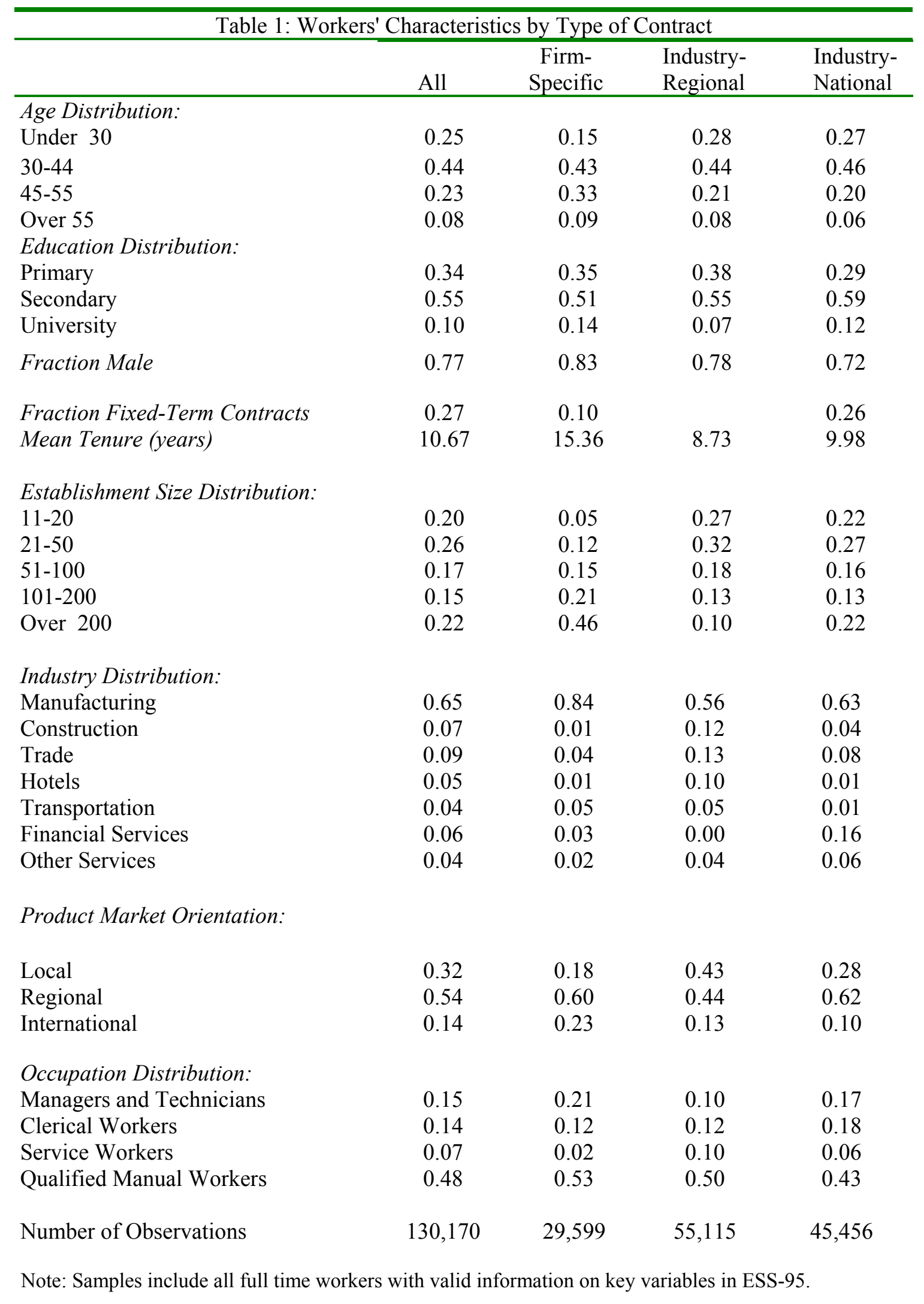


Table 2: Mean Log Wages by Type of Contract

\begin{tabular}{lcccc}
\hline & $\begin{array}{c}\text { Mean Log } \\
\text { Wage }\end{array}$ & $\begin{array}{c}\text { Standard } \\
\text { Deviation }\end{array}$ & $\begin{array}{c}\text { Standardized } \\
\text { Mean Log } \\
\text { Wage }\end{array}$ & $\begin{array}{c}\text { Standardized } \\
\text { Standard } \\
\text { Deviation }\end{array}$ \\
\hline All Workers & & & & \\
Overall & 6.79 & 0.51 & & \\
Firm Contract & 7.06 & 0.47 & 6.89 & 0.51 \\
Regional Contract & 6.67 & 0.46 & 6.78 & 0.46 \\
National Contract & 6.78 & 0.53 & 6.76 & 0.49 \\
Males & & & & \\
Overall & 6.85 & 0.51 & & 0.50 \\
Firm Contract & 7.10 & 0.46 & 6.95 & 0.48 \\
Regional Contract & 6.73 & 0.45 & 6.82 & \\
National Contract & 6.86 & 0.54 & 6.82 & 0.49 \\
Females & & & & 0.41 \\
Overall & & & & 0.43 \\
Firm Contract & 6.59 & 0.45 & 6.69 & \\
Regional Contract & 6.88 & 0.49 & 6.59 & \\
National Contract & 6.58 & 0.39 & 6.56 &
\end{tabular}

Note: Standardized mean and standard deviation are obtained from weighted sample, using DiNardo, Fortín, Lemieux (1996) procedure. Samples are 130,170 for all workers, 100,533 for males and 29,637 for females. 


\begin{tabular}{|c|c|c|c|c|c|c|}
\hline & \multicolumn{3}{|c|}{ Men } & \multicolumn{3}{|c|}{ Women } \\
\hline & [1] & [2] & [3] & {$[1]$} & {$[2]$} & [3] \\
\hline Firm Contract & $\begin{array}{c}0.317 \\
(0.013)\end{array}$ & $\begin{array}{c}0.082 \\
(0.012)\end{array}$ & $\begin{array}{c}0.074 \\
(0.009)\end{array}$ & $\begin{array}{c}0.343 \\
(0.024)\end{array}$ & $\begin{array}{c}0.126 \\
(0.015)\end{array}$ & $\begin{array}{c}0.108 \\
(0.012)\end{array}$ \\
\hline \multicolumn{7}{|l|}{ Worker's Skills } \\
\hline Education & & $\begin{array}{c}0.026 \\
(0.0009)\end{array}$ & $\begin{array}{c}0.024 \\
(0.001)\end{array}$ & & $\begin{array}{c}0.021 \\
(0.001)\end{array}$ & $\begin{array}{c}0.017 \\
(0.001)\end{array}$ \\
\hline Age & & $\begin{array}{c}0.011 \\
(0.0002)\end{array}$ & $\begin{array}{c}0.010 \\
(0.0002)\end{array}$ & & $\begin{array}{c}0.010 \\
(0.0004)\end{array}$ & $\begin{array}{c}0.008 \\
(0.0004)\end{array}$ \\
\hline Fixed-Term contract & & $\begin{array}{l}-0.198 \\
(0.006)\end{array}$ & $\begin{array}{l}-0.183 \\
(0.005)\end{array}$ & & $\begin{array}{l}-0.170 \\
(0.011)\end{array}$ & $\begin{array}{c}-0.155 \\
(0.012)\end{array}$ \\
\hline \multicolumn{7}{|c|}{ Firm's Characteristics (ref: Local product market, privately owned, 10-20 workers) } \\
\hline National Market & & $\begin{array}{c}0.050 \\
(0.009)\end{array}$ & $\begin{array}{c}0.048 \\
(0.007)\end{array}$ & & $\begin{array}{c}0.055 \\
(0.010)\end{array}$ & $\begin{array}{c}0.048 \\
(0.009)\end{array}$ \\
\hline International Market & & $\begin{array}{c}0.064 \\
(0.015)\end{array}$ & $\begin{array}{c}0.060 \\
(0.011)\end{array}$ & & $\begin{array}{c}0.075 \\
(0.018)\end{array}$ & $\begin{array}{c}0.062 \\
(0.017)\end{array}$ \\
\hline Publicly Owned & & $\begin{array}{c}0.061 \\
(0.042)\end{array}$ & $\begin{array}{c}0.060 \\
(0.033)\end{array}$ & & $\begin{array}{c}0.129 \\
(0.040)\end{array}$ & $\begin{array}{c}0.142 \\
(0.033)\end{array}$ \\
\hline 20-50 Workers & & $\begin{array}{c}0.062 \\
(0.009)\end{array}$ & $\begin{array}{c}0.062 \\
(0.007)\end{array}$ & & $\begin{array}{c}0.020 \\
(0.011)\end{array}$ & $\begin{array}{c}0.017 \\
(0.011)\end{array}$ \\
\hline 51-100 Workers & & $\begin{array}{c}0.120 \\
(0.012)\end{array}$ & $\begin{array}{c}0.121 \\
(0.010)\end{array}$ & & $\begin{array}{c}0.066 \\
(0.014)\end{array}$ & $\begin{array}{c}0.053 \\
(0.013)\end{array}$ \\
\hline 101-200 Workers & & $\begin{array}{c}0.132 \\
(0.012)\end{array}$ & $\begin{array}{c}0.135 \\
(0.010)\end{array}$ & & $\begin{array}{c}0.105 \\
(0.016)\end{array}$ & $\begin{array}{c}0.083 \\
(0.015)\end{array}$ \\
\hline Over 200 Workers & & $\begin{array}{c}0.202 \\
(0.013)\end{array}$ & $\begin{array}{c}0.204 \\
(0.011)\end{array}$ & & $\begin{array}{c}0.158 \\
(0.014)\end{array}$ & $\begin{array}{c}0.132 \\
(0.013)\end{array}$ \\
\hline \multicolumn{7}{|c|}{ Average Characteristics of Co-workers in Same Firm and Occupation Group } \\
\hline Education & & & $\begin{array}{c}0.004 \\
(0.002)\end{array}$ & & & $\begin{array}{c}0.007 \\
(0.002)\end{array}$ \\
\hline Age & & & $\begin{array}{c}0.003 \\
(0.0009)\end{array}$ & & & $\begin{array}{c}0.005 \\
(0.001)\end{array}$ \\
\hline Proportion Under 30 & & & $\begin{array}{c}-0.085 \\
(0.016)\end{array}$ & & & $\begin{array}{c}-0.034 \\
(0.021)\end{array}$ \\
\hline Proportion Over 50 & & & $\begin{array}{l}-0.109 \\
(0.020)\end{array}$ & & & $\begin{array}{l}-0.147 \\
(0.030)\end{array}$ \\
\hline Proportion Female & & & $\begin{array}{l}-0.052 \\
(0.016)\end{array}$ & & & $\begin{array}{c}-0.155 \\
(0.014)\end{array}$ \\
\hline Intercept & $\begin{array}{c}6.789 \\
(0.003)\end{array}$ & $\begin{array}{c}5.88 \\
(0.020)\end{array}$ & $\begin{array}{c}5.84 \\
(0.039)\end{array}$ & $\begin{array}{c}6.53 \\
(0.003)\end{array}$ & $\begin{array}{c}5.75 \\
(0.029)\end{array}$ & $\begin{array}{c}5.78 \\
(0.06)\end{array}$ \\
\hline R-squared & 0.068 & 0.507 & 0.511 & 0.07 & 0.496 & 0.508 \\
\hline
\end{tabular}

Notes. All models except [1] also include 16 indicators for region, 4 indicators for occupation and 6 indicators for industry. Sample size for all models is 100,533 for men and 29,637 for women. Standard errors are calculated with clustering by firms. 


\begin{tabular}{lcc}
\hline \multicolumn{3}{c}{ Table 4: Log Wage Regressions - p-score value added as a regressor } \\
\hline Firm Contract & MEN & WOMEN \\
& 0.053 & 0.069 \\
Propensity score & $(0.010)$ & $(0.012)$ \\
& 0.609 & 0.024 \\
Squared propensity score & $(0.113)$ & $(0.167)$ \\
& -1.08 & 0.635 \\
Cubed propensity Score & $(0.312)$ & $(0.468)$ \\
& 0.703 & -0.383 \\
& $(0.237)$ & $(0.364)$ \\
\hline R-squared & & 0.514 \\
\hline
\end{tabular}

Note: Although not reported, estimations also include all covariates included in model [3] of Table 3, i.e, individual observable skills, job characteristics, average skills of the co-workers, plus 16 indicators for region, 4 indicators for occupation and 6 indicators for industry. Sample size is 100,533 for men and 29,637 for women. Standard errors are calculated with clustering by firms. 
Table 5: Estimation of Firm-Contract Effect by Wage Quintile

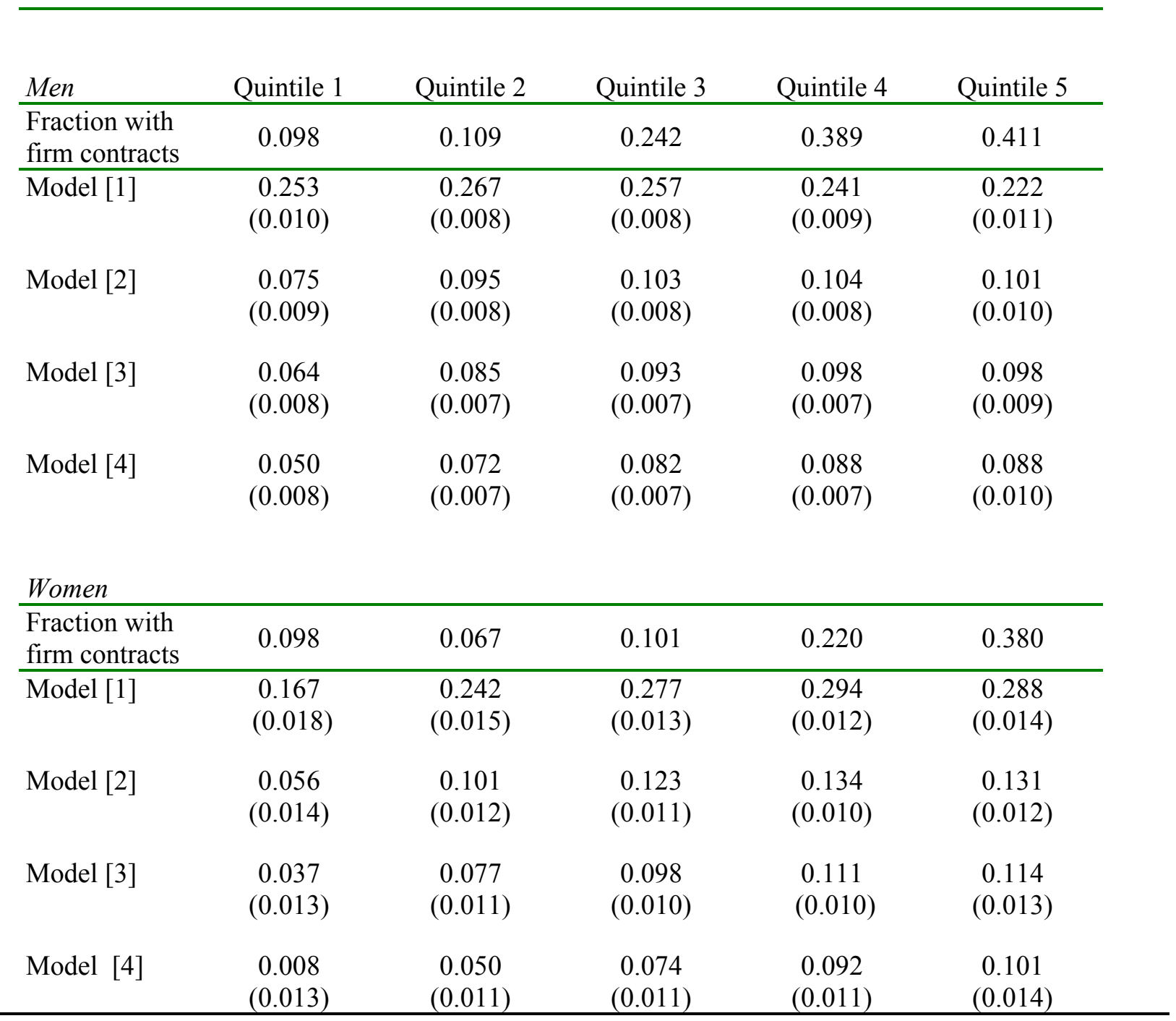

Notes: Models [1] to [3] correspond to specifications in Table 3. Model [4] correspond to specifications in Table 4. Samples include 100,533 men and 29,637 women. Standard errors are calculated with clustering by firms. 
Table 6: Models for Worker Tenure

\begin{tabular}{|c|c|c|c|c|c|c|}
\hline & \multicolumn{3}{|c|}{ Men } & \multicolumn{3}{|c|}{ Women } \\
\hline & [1] & [2] & [3] & [1] & [2] & [3] \\
\hline Firm Contract & $\begin{array}{c}4.90 \\
(0.22)\end{array}$ & $\begin{array}{c}2.21 \\
(0.19)\end{array}$ & $\begin{array}{l}-14.63 \\
(3.05)\end{array}$ & $\begin{array}{c}4.04 \\
(0.30)\end{array}$ & $\begin{array}{c}2.05 \\
(0.18)\end{array}$ & $\begin{array}{l}-0.73 \\
(6.05)\end{array}$ \\
\hline $\begin{array}{l}\text { Firm Contract* } \\
\text { Predicted Wage }\end{array}$ & & & $\begin{array}{c}2.42 \\
(0.44)\end{array}$ & & & $\begin{array}{c}0.41 \\
(0.90)\end{array}$ \\
\hline Education & & $\begin{array}{l}-0.13 \\
(0.01)\end{array}$ & $\begin{array}{l}-0.15 \\
(0.01)\end{array}$ & & $\begin{array}{l}-0.17 \\
(0.02)\end{array}$ & $\begin{array}{l}-0.17 \\
(0.03)\end{array}$ \\
\hline \multicolumn{7}{|c|}{ Market Orientation (ref: Local Market) } \\
\hline National Market & & $\begin{array}{c}0.70 \\
(0.16)\end{array}$ & $\begin{array}{c}0.71 \\
(0.16)\end{array}$ & & $\begin{array}{c}1.01 \\
(0.17)\end{array}$ & $\begin{array}{c}1.01 \\
(0.22)\end{array}$ \\
\hline International Market & & $\begin{array}{c}0.73 \\
(0.25)\end{array}$ & $\begin{array}{c}0.68 \\
(0.25)\end{array}$ & & $\begin{array}{c}0.74 \\
(0.22)\end{array}$ & $\begin{array}{c}0.74 \\
(0.33)\end{array}$ \\
\hline \multicolumn{7}{|c|}{ Firm's Size (ref: 10-20 Workers) } \\
\hline 21-50 Workers & & $\begin{array}{c}0.45 \\
(0.17)\end{array}$ & $\begin{array}{c}0.47 \\
(0.17)\end{array}$ & & $\begin{array}{c}0.64 \\
(0.20)\end{array}$ & $\begin{array}{c}0.64 \\
(0.25)\end{array}$ \\
\hline 51-100 Workers & & $\begin{array}{c}1.67 \\
(0.20)\end{array}$ & $\begin{array}{c}1.69 \\
(0.20)\end{array}$ & & $\begin{array}{c}1.48 \\
(0.21)\end{array}$ & $\begin{array}{c}1.48 \\
(0.29)\end{array}$ \\
\hline 101-200 Workers & & $\begin{array}{c}2.28 \\
(0.23)\end{array}$ & $\begin{array}{c}2.31 \\
(0.23)\end{array}$ & & $\begin{array}{c}2.14 \\
(0.21)\end{array}$ & $\begin{array}{c}2.14 \\
(0.31)\end{array}$ \\
\hline Over 200 workers & & $\begin{array}{c}3.78 \\
(0.22)\end{array}$ & $\begin{array}{c}3.73 \\
(0.22)\end{array}$ & & $\begin{array}{c}3.22 \\
(0.22)\end{array}$ & $\begin{array}{c}3.21 \\
(0.32)\end{array}$ \\
\hline Public firm & & $\begin{array}{c}1.17 \\
(0.67)\end{array}$ & $\begin{array}{c}0.48 \\
(0.66)\end{array}$ & & $\begin{array}{c}1.34 \\
(0.57)\end{array}$ & $\begin{array}{l}1.18 \\
(0.63)\end{array}$ \\
\hline R-squared & 0.39 & 0.47 & 0.47 & 0.34 & 0.42 & 0.42 \\
\hline
\end{tabular}

Notes: Dependent variable is years of employment at current firm. Samples include only workers age 25-65. All models include full set of dummies for each single year of age. Specifications [2] and [3] also include 16 indicators for region, 4 indicators for occupation and 6 indicators for industry. Predicted wage included as interaction with firm contract indicator in specification [3] is based on regression model fit on subsample of workers with sectoral contract, using same covariates included as main effects in specifications [2] and [3]. Standard errors are calculated with clustering by firms. 


\begin{tabular}{|c|c|c|c|c|}
\hline \multicolumn{5}{|c|}{$\begin{array}{l}\text { Table A1: Log Wage Regressions with Alternative Co-workers' Groupings } \\
\text { Men }\end{array}$} \\
\hline & [1] & [2] & [1] & [2] \\
\hline Firm Contract & $\begin{array}{c}0.063 \\
(0.011)\end{array}$ & $\begin{array}{c}0.072 \\
(0.008)\end{array}$ & $\begin{array}{l}0.096 \\
(0.014)\end{array}$ & $\begin{array}{c}0.112 \\
(0.011)\end{array}$ \\
\hline \multicolumn{5}{|l|}{ Worker's skills } \\
\hline Education & $\begin{array}{c}0.022 \\
(0.0008)\end{array}$ & $\begin{array}{l}0.011 \\
(0.001)\end{array}$ & $\begin{array}{c}0.014 \\
(0.001)\end{array}$ & $\begin{array}{c}0.009 \\
(0.002)\end{array}$ \\
\hline Age & $\begin{array}{c}0.010 \\
(0.0002)\end{array}$ & $\begin{array}{c}0.007 \\
(0.0002)\end{array}$ & $\begin{array}{c}0.009 \\
(0.0004)\end{array}$ & $\begin{array}{l}0.006 \\
(0.0005)\end{array}$ \\
\hline Fixed-Term Contract & $\begin{array}{l}-0.179 \\
(0.006)\end{array}$ & $\begin{array}{l}-0.174 \\
(0.005)\end{array}$ & $\begin{array}{l}-0.150 \\
(0.011)\end{array}$ & $\begin{array}{l}-0.150 \\
(0.012)\end{array}$ \\
\hline \multicolumn{5}{|c|}{ Firm's Characteristics (ref: Local product market, privately owned,10-20 workers) } \\
\hline National Market & $\begin{array}{c}0.042 \\
(0.009)\end{array}$ & $\begin{array}{c}0.046 \\
(0.007)\end{array}$ & $\begin{array}{c}0.042 \\
(0.010)\end{array}$ & $\begin{array}{c}0.049 \\
(0.009)\end{array}$ \\
\hline International Market & $\begin{array}{c}0.053 \\
(0.014)\end{array}$ & $\begin{array}{c}0.059 \\
(0.009)\end{array}$ & $\begin{array}{c}0.060 \\
(0.017)\end{array}$ & $\begin{array}{c}0.065 \\
(0.016)\end{array}$ \\
\hline Publicly Owned & $\begin{array}{c}0.059 \\
(0.041)\end{array}$ & $\begin{array}{c}0.060 \\
(0.024)\end{array}$ & $\begin{array}{c}0.139 \\
(0.039)\end{array}$ & $\begin{array}{c}0.138 \\
(0.031)\end{array}$ \\
\hline 21-50 Workers & $\begin{array}{c}0.063 \\
(0.008)\end{array}$ & $\begin{array}{c}0.062 \\
(0.007)\end{array}$ & $\begin{array}{c}0.022 \\
(0.011)\end{array}$ & $\begin{array}{c}0.016 \\
(0.010)\end{array}$ \\
\hline 51-100 Workers & $\begin{array}{c}0.121 \\
(0.011)\end{array}$ & $\begin{array}{c}0.120 \\
(0.008)\end{array}$ & $\begin{array}{c}0.063 \\
(0.013)\end{array}$ & $\begin{array}{c}0.058 \\
(0.012)\end{array}$ \\
\hline 101-200 Workers & $\begin{array}{c}0.124 \\
(0.012)\end{array}$ & $\begin{array}{c}0.136 \\
(0.009)\end{array}$ & $\begin{array}{c}0.096 \\
(0.017)\end{array}$ & $\begin{array}{c}0.085 \\
(0.014)\end{array}$ \\
\hline Over 200 Workers & $\begin{array}{c}0.202 \\
(0.012)\end{array}$ & $\begin{array}{c}0.204 \\
(0.009)\end{array}$ & $\begin{array}{c}0.145 \\
(0.014)\end{array}$ & $\begin{array}{c}0.133 \\
(0.012)\end{array}$ \\
\hline \multicolumn{5}{|c|}{ Average Characteristics of Co-workers in Same Firm and Occupation Group } \\
\hline Education & $\begin{array}{c}0.011 \\
(0.002)\end{array}$ & $\begin{array}{c}0.021 \\
(0.004)\end{array}$ & $\begin{array}{c}0.017 \\
(0.002)\end{array}$ & $\begin{array}{c}0.017 \\
(0.002)\end{array}$ \\
\hline Age & $\begin{array}{c}0.004 \\
(0.002)\end{array}$ & $\begin{array}{c}0.007 \\
(0.0007)\end{array}$ & $\begin{array}{c}0.005 \\
(0.002)\end{array}$ & $\begin{array}{c}0.007 \\
(0.001)\end{array}$ \\
\hline Proportion Under 30 & $\begin{array}{l}-0.124 \\
(0.032)\end{array}$ & $\begin{array}{l}-0.091 \\
(0.012)\end{array}$ & $\begin{array}{c}-0.048 \\
(0.036)\end{array}$ & $\begin{array}{c}-0.056 \\
(0.017)\end{array}$ \\
\hline Proportion Over 50 & $\begin{array}{l}-0.172 \\
(0.040)\end{array}$ & $\begin{array}{c}-0.093 \\
(0.014)\end{array}$ & $\begin{array}{l}-0.112 \\
(0.052)\end{array}$ & $\begin{array}{l}-0.129 \\
(0.024)\end{array}$ \\
\hline Proportion Female & $\begin{array}{l}-0.074 \\
(0.020)\end{array}$ & $\begin{array}{l}-0.097 \\
(0.016)\end{array}$ & $\begin{array}{l}-0.174 \\
(0.019)\end{array}$ & $\begin{array}{l}-0.150 \\
(0.014)\end{array}$ \\
\hline R-squared & 0.513 & 0.517 & 0.512 & 0.512 \\
\hline
\end{tabular}

Note: See notes to Table 3. In specification [1], co-workers consist of all employees at the same workplace. In specification [2], co-workers consist of all employees at the same workplace in the same 2-digit occupation group (53 groups). All models include 16 indicators for region, 4 indicators for occupation, and 6 indicators for industry. Standard errors are calculated with clustering by firms. 
Table A2: Ordered Probit model for the Probability of Being in Different Wage Quintiles

\begin{tabular}{lcc}
\hline & Men & Women \\
\hline Age & 0.038 & 0.041 \\
& $(0.0006)$ & $(0.001)$ \\
Education & 0.101 & 0.091 \\
& $(0.002)$ & $(0.003)$ \\
Fixed-term contract & -0.839 & -0.720 \\
& $(0.014)$ & $(0.022)$ \\
Occupations (reference: Non-Qualified Manual) \\
Managers and & 0.601 & 1.076 \\
Technicians & $(0.023)$ & $(0.043)$ \\
Clerical & 0.061 & 0.368 \\
& $(0.023)$ & $(0.032)$ \\
Service & -0.408 & -0.015 \\
& $(0.028)$ & $(0.032)$ \\
Qualified Manual & -0.004 & 0.090 \\
& $(0.016)$ & $(0.028)$ \\
Pseudo-R & & \\
Number of Observations & 100,533 & 0.148 \\
Note: See text. Models are ordered & 29,637 \\
\hline
\end{tabular}

Note: See text. Models are ordered probit models with 5 ranges based on unconditional quintiles of gender-specific wage distribution. Robust standard errors in parentheses. 

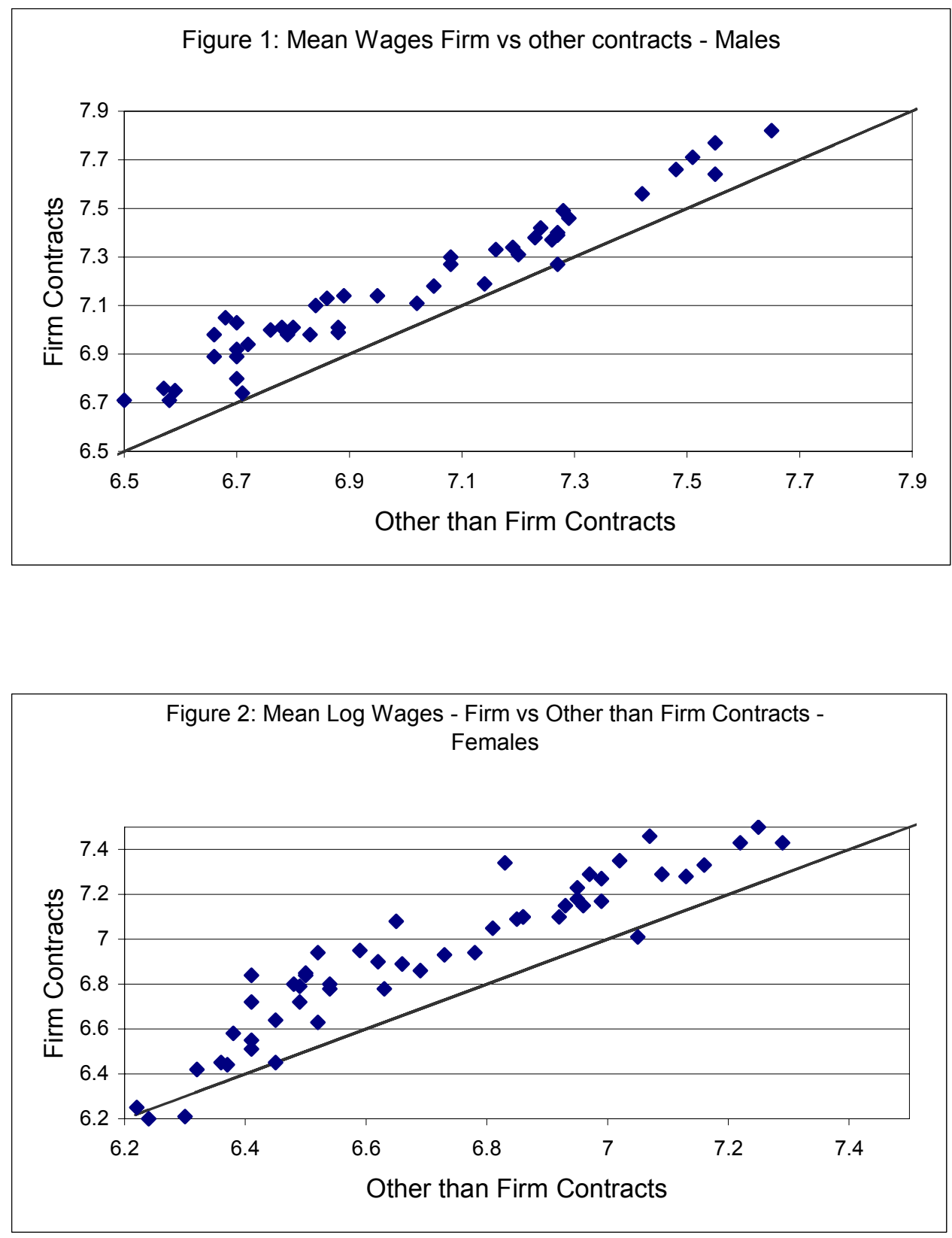